\title{
粘土瓦の内表面の改質による耐凍害性の向上
}

\author{
中村雅彦・奥田 進* \\ $\left(\begin{array}{l}\text { 京都工芸瀻維大学 工芸学部 無機材料工学科 } \\ * \text { 現在 }\end{array}\right.$

\section{Enhancement of Frost Durability by Modification of Internal Surface of Clay Roofing Tiles}

\author{
Masahiko NAKAMURA and Susumu OKUDA* \\ $\left(\begin{array}{l}\text { Department of Inorganic Materials, Faculty of Engineering and Design, Kyoto Institute of Technology } \\ \text { Matsugasaki, Sakyo-ku, Kyoto-shi } 606\end{array}\right)$ \\ * At present, The Kansai Women's Art College
}

\begin{abstract}
The possibility of surface modification of a hydrophilic hydroxy group on silica surface to a hydrophobic butoxy group was investigated on clay roofing tile specimens, and the enhancement in frost durability was experimentally confirmed. The internal surface modification was undertaken by reflux-boiling of rectangular shaped specimens $(2.5 \mathrm{~cm} \times 2.5 \mathrm{~cm}, 1.8 \mathrm{~cm}$ in thickness) in pure n-butanol for 24hours. The formation of butoxy group on the internal surface of clay roofing tiles was experimentally confirmed by comparing IR spectra and water absorption between surface-modified and non-modified specimens of clay roofing tiles. The surface modification enhanced the frost durability of clay roofing tiles.
\end{abstract}

[Received April 25, 1986]

Key-words : Frost-durability, Roofing tyle, Surface modification, Butoxy-group, Hydroxyl-group, Internal surface

\section{1. 緒 言}

建築用の無機多孔質製品の耐凍害性の改善に関して は, 凍害の発生機構に関連する因子に注目して, 幾つか の方法が構じられている. その代表的な方法としては, 材料の気孔組織, 例えば, 気孔径分布のうちで, 凍害を 誘発しやすい気孔径を有する気孔量を, 素地の焼成条件, 硬化条件, 出発原料の鉱物組成及び粒度配合を調節する ことによって低減させたり，機械的強度を高めるという 物理的手法が採用されている. 他の方法としては, 多孔 質体の内表面を種々の改質技術によって疎水化させるこ とにより，水に対する親和性を低下させるという化学的 手法がある。これには多孔質体中に改質用媒体を吸収さ せて, 内表面上に揆水性（疎水性）の被膜を付着, 形成 させる方法があるが，固体表面と被膜との結合様式とし て, van der Waals 力のような物理的付着力によるか, 固体表面の不飽和化学結合サイトへの官能基の化学的結 合力によるかは, 表面改質の処理技法によって決まる. 著者らは, 凍害機構を探る現在までの一連の研究を通じ て, 凍害発生の主要因の一つとして, 以下のような考え をもっている文 . すなわち, 多孔質体中の気孔内の水 の凍結は, 大きい気孔内の自由水ほど凍結しやすいこと, 及び各種の大きさの気孔や，それら気孔をつなぐ毛細管 の 3 次元的連結組織内で氷が成長, 伝播していくことな ビの現象が重なり合って, 冷却中に微細な気孔や毛細管 内には, 先に凍結した氷によって一時的に未凍結状態で
自由水が閉塞される. 更に系が冷却されると，上述の閉 塞水の凍結に伴って発生する局所的な静水圧力が, 多孔 組織内での微細なぜい弱な欠陥部分に応力集中を繰り返 えし, 凍結融解サイクルのうちに, 徐々に組織破壊が進 行, 拡大して, 遂には剝落していく。このような凍害機 構の考え方に基づいて, 上述の気孔内表面の改質による 耐凍害性の向上に対するねらいは, 内表面の疎水性化に よって, 固体表面に対する水の濡れ性を低下させて, 微 細気孔や毛細管内への水分の侵入をできるかぎり減らす ことにより, 一時的な未凍結閉塞水量を軽減させ, 局所 的静水圧力の発生が起こっても, 水あるいは固体表面の 束縛水 ${ }^{4)}$ の微小移動により破壊圧力を緩和できる空間を 多孔組織内に保有させることを本研究では目指してい る.

表面改質には，一般に粉体に対して行われる種々のプ ロセスがあり，これら諸手法が多孔材料の内表面改質に 有用であることは言うまでもない.しかし，改質表面の 化学的耐久性や改質費用の点で, 低廉で, しかも長期間 の使用を必要とする無機建材に適した改質技術は多くな い. 著者らは，上述の経費的条件も考慮に入れて，シリ カの表面水酸基をブトキシ基に置換し, 表面を踈水性に 改質する簡便な技術 ${ }^{5)} に$ 着目し, 粘土瓦の主要構成成分 である，シリカが瓦内表面に露出する部分をブトキシ基 に改質することにより, どの程度瓦試料の耐凍害性が改 善されるかを検討した。 


\section{2. 実 験}

\section{1 試料}

無機建材試料には，実際に工場で製造されている粘土 瓦の真空押し出し後, 乾燥させた栈瓦用の実寸法大の無 釉素地を, 気孔率を 2 種に変化させる目的で, $800^{\circ} \mathrm{C}$ 及 び $900^{\circ} \mathrm{C}$ で 2 時間焼成したものを準備した。焼成瓦か ら, $2.5 \mathrm{~cm} \times 2.5 \mathrm{~cm}$, 厚さ $1.8 \mathrm{~cm}$ に切り出し, 表面改 質用の試料とした。瓦試料の化学組成を表 1 に示す.

表面改質のための媒液には，市販の $n$-ブタノールを 用いた．上記の焼成温度の異なる 2 種の瓦試料の比表面 積は BET 吸着による一点法により求めた。

\section{2 表面改質法}

上述の焼成温度の異なる 2 種の瓦切り出し試料を, $100^{\circ} \sim 110^{\circ} \mathrm{C}$ で 24 時間乾燥し, 室温に冷却した後各 3 個ずつ，合計 6 個を $500 \mathrm{cc}$ の $n$-ブタノールを入れた容 量 $1 l$ のつロフラスコ内に浸漬し，マントルヒーター にて，n-ブタノールの沸点 $\left(117^{\circ} \mathrm{C}\right)$ で 24 時間還流者 沸した。フラスコの各口にはジムロート冷却器, 温度計 及び突沸防止のガラス栓の圧力抜き弁を取り付け，ブタ ノール蒸気の逸散の防止及び温度調節を行った。

Table 1. Analytical chemical composition of clay roofing tile specimen for internal surface modification by $n$-butanol.

\begin{tabular}{lc}
\hline $\begin{array}{c}\text { Chemical } \\
\text { component }\end{array}$ & $\begin{array}{c}\text { Composition } \\
\text { (wt } 8)\end{array}$ \\
\hline $\mathrm{SiO}_{2}$ & 67.4 \\
$\mathrm{Al}_{2} \mathrm{O}_{3}$ & 15.9 \\
$\mathrm{Fe}_{2} \mathrm{O}_{3}$ & 7.2 \\
$\mathrm{MgO}$ & 1.3 \\
$\mathrm{CaO}$ & 0.3 \\
$\mathrm{Na}_{2} \mathrm{O}$ & 2.1 \\
$\mathrm{~K}_{2} \mathrm{O}$ & 1.8 \\
Ig.-loss & 5.2 \\
\hline Total & 101.2 \\
\hline
\end{tabular}

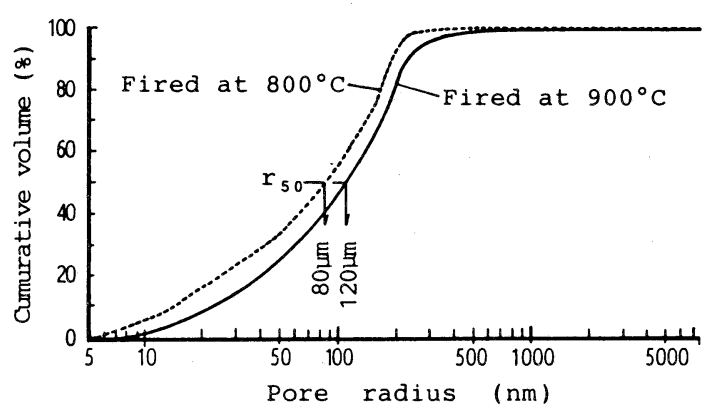

Fig. 1. Comparison of pore size distribution of clay roofing tiles fired at different temperatures.

\section{3 表面改質効果の確認}

上述で改質を行った矩形試料の内部に残留する未反応 のブタノール液を除却するために，アセトン中への浸漬 及び乾燥を数回繰り返した後, デシケーター中にて乾燥 保存した。表面改質効果の確認は，改質及び未改質の両 試料の一定条件下での吸水率測定や,矩形試料を粉砕し, $\mathrm{KBr}$ 法による赤外吸収スペクトル分析の比較によって 行った. 吸水率の測定は, 室温静止水中に 24 時間浸漬後, 引続き回転式真空ポンプにて発泡が認められなくなるま で（約 3 時間程度）飽水させる方法によった。吸水率値 は，水中浸漬前の乾燥試料重量に対する各吸水重量の百 分率として表した。気孔径分布は, 気孔半径が $5 \mathrm{~nm}$ $7.5 \mu \mathrm{m}$ の範囲に対して測定可能な水銀圧入式ポロシ メー夕を用いて決定した. 瓦試料の気孔径分布を図 1 に 比較して示す.

\section{4 而凍害性の評価法}

表面改質処理を行った試料及び同寸法の未処理試料 $(2.5 \mathrm{~cm} \times 2.5 \mathrm{~cm}$ ，厚さ $1.8 \mathrm{~cm})$ を水中浸漬状態で回 転真空ポンプ脱気により試料内に水分を充満したものを 耐凍害性試験に供した。試験には，著者らが開発した熱 電冷却素子を用いた一方向凍結融解装置を用いた ${ }^{6}$. 冷 却基板表面の温度降下及び上昇速度を $7^{\circ} \mathrm{C} / \mathrm{min}$ とし, 飽水試料底部を $-42^{\circ} \mathrm{C}$ まで, 上部を一 $-32^{\circ} \mathrm{C}$ まで冷却し, 融解後, 試料底部及び上部が冷却開始時の温度に平衡に 達するまで保持したときに，試料の冷却方向（瓦の厚さ 方向）に残留する線膨張率の值を凍害破壊の程度として 表した．瓦は押し出し及び加圧形成時の素地の流れによ る組織内欠陥が多かれ少なかれ潜在し，これら欠陥（例 えば，ラミネーション）による層状破壊は，常に瓦の成 形圧力の印加方向に直角に現れるため, 瓦試料の場合に は, 厚さ方向の残留線膨張率が凍害破壊の最も有効な目 安となる7!。測定には，最小読み取り精度が記録紙上で $1 \mu \mathrm{m}$ となる差動トランスを用いた。凍結融解中に飽水 試料から蒸発により含水率が減少するのを防ぐために, 試料上面で差動トランスのコアーが試料面に接触する部 分を除いて, 湿潤した布を載せ，試料系を発泡スチロー ル製の断熱板でカバーした。

\section{3. 結果と考察}

\section{1 表面改質の確認}

表面改質試料の各吸水率が未処理試料に比較してどの 程度低下するかを表 2 にまとめて示す．表 2 から明らか なように表面改質試料では，未処理試料に比べて約 6 7 割程度の吸水率の低下がみられる。吸水率の低下の程 度は, 24 時間水中浸漬条件の方が著しく, 真空飽水条 件下でも未処理試料に比較して吸水しにくいことが分か る. 焼成温度の影響をみると, $800^{\circ} \mathrm{C}$ の焼成試料の方が $900^{\circ} \mathrm{C}$ 焼成試料に比べて吸水率の低下の程度が大きく, 
Table 2. Comparison of water absorption and saturation coefficient of specimens before or after internal surface modification of clay roofing tile fired at different temperatures.

\begin{tabular}{|c|c|c|}
\hline \multirow{2}{*}{$\begin{array}{l}\text { Condition of } \\
\text { specimen }\end{array}$} & \multicolumn{2}{|c|}{$\begin{array}{l}\text { Water absorption and } \\
\text { (saturation coeff.) }\end{array}$} \\
\hline & $\begin{array}{l}\text { Before } \\
\text { modification }\end{array}$ & $\begin{array}{l}\text { After } \\
\text { modification }\end{array}$ \\
\hline $\begin{array}{l}\text { "Specimen fired } \\
\text { at } 800^{\circ} \mathrm{C} "\end{array}$ & $(0.93) *$ & $(0.86)^{\star}$ \\
\hline $\begin{array}{l}\text { Dipped in water } \\
\text { for } 24 \mathrm{hrs}\end{array}$ & 12.51 wt & $7.22 w t \%$ \\
\hline $\begin{array}{l}\text { Sorbed water } \\
\text { under vacuum }\end{array}$ & $13.73 w t \frac{0}{0}$ & 8. 38wt\% \\
\hline $\begin{array}{l}\text { "Specimen fired } \\
\text { at } 900^{\circ} \mathrm{C} "\end{array}$ & $(0.92)^{\star}$ & $(0.87)^{\star}$ \\
\hline $\begin{array}{l}\text { Dipped in water } \\
\text { for } 24 \mathrm{hrs}\end{array}$ & $12.15 \mathrm{wt} z$ & $8.89 w t \%$ \\
\hline $\begin{array}{l}\text { Sorbed water } \\
\text { under vacuum }\end{array}$ & $13.26 \mathrm{wt} z$ & $10.17 \mathrm{wt} z$ \\
\hline
\end{tabular}

$800^{\circ} \mathrm{C}$ 焼成試料の方が表面改質効果が顕著であることが 推定される。この理由としては, 例えば, 試料内表面に 露出するシリカ表面のシラノ一ル基の $n$-ブ夕ノールと の反応による疎水性化の相違として, 以下のように推測 される.すなわち, シリカ表面のシラノ一ルは次の三者 が存在すると言われている ${ }^{8)}$.
(a) $>\mathrm{Si}-\mathrm{OH}$
(b) $>\mathrm{Si}<\mathrm{OH}$
(c) $>\stackrel{\text { S }}{\mathrm{S}} \mathrm{i}-\mathrm{O}-\stackrel{\mathrm{O}}{\mathrm{S}} \mathrm{i}<$

これら 3 種類の水酸基は, $n$-ブタノールとのエステ ル化反応により, $-\mathrm{OH} \rightarrow-\mathrm{OC}_{4} \mathrm{H}_{9}$, 表面は疎水性化して いく5). シリカを加熱していくと, 表面シラノールは互 いに隣接する 2 個の水酸基から 1 分子の水が脱水縮合し て, シロキサン結合 $(>\mathrm{Si}-\mathrm{O}-\mathrm{Si}<)$ が生成し, 加熱温 度が高くなるほよ゙シロキサン結合数が増加し, 再水和が 容易な残存シラノ一ル数が減少する. すなわち, 本実験 の場合には, $800^{\circ} \mathrm{C}$ 焼成瓦試料の方が $900^{\circ} \mathrm{C}$ 焼成瓦試 料よりも残存水酸基が多く, ブトキシ化による疎水性化 は高いと考えられる，他方，焼成温度の違いによる瓦試 料の比表面積值の相違は, $800^{\circ} \mathrm{C}$ 焼成瓦では $17.5 \mathrm{~m}^{2} / \mathrm{g}$, $900^{\circ} \mathrm{C}$ 焼成瓦では $9.6 \mathrm{~m}^{2} / \mathrm{g}$ であり, 前者の方が約 2 倍

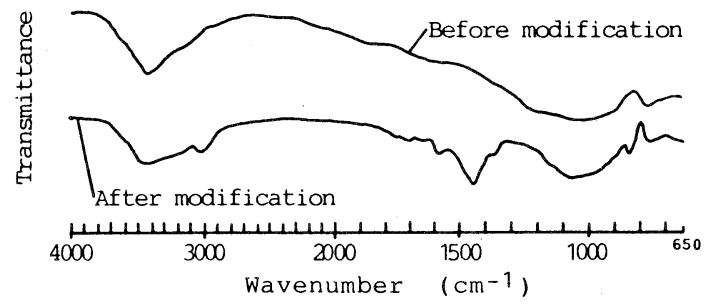

Fig. 2. Comparison of IR spectra by $\mathrm{KBr}$ method of powdered clay roofing tile specimens before or after internal surface modification by $\mathrm{n}$-butanol.
大きく, 単位表面積当たりに露出するシラノール数の差 が疎水性化の程度に差異をもたらす一要因となると考え られる。

次に, 表面の疎水化の程度が大きい $800^{\circ} \mathrm{C}$ 焼成瓦試 料の赤外吸収スペクトル分析の結果を図 2 に比較して示 す. 未処理の瓦試料では, 表面水酸基の伸縮振動と思わ れる約 $3450 \mathrm{~cm}^{-1}$ にのみ吸収ピークが認められるのに対 し, 改質処理試料では, $1480 \mathrm{~cm}^{-1}$ に明白な吸収ピーク と, $2900 \mathrm{~cm}^{-1}$ 近傍及び $1600 \mathrm{~cm}^{-1}$ 付近に弱い吸収ピー クが認められる.これらは, $\mathrm{CH}$ 結合の伸縮振動並びに 変角振動に帰属するものであり, 瓦表面には, ブトキシ 基が置換していることが分かる. しかし, 改質処理瓦で も約 $3450 \mathrm{~cm}^{-1}$ の表面水酸基の伸縮振動による弱い吸収 ピークが認められ, 若干のシラノールは残留しているよ うである. 赤外吸収ピークが鮮明でないのは, 塊状の改 質瓦を粉砕して測定を行ったため, 置換置の濃度が希薄 であり，装置の分解能の制約によるためと思われる。ま た, 改質後のブトキシ基の加水分解反応, $-\mathrm{OC}_{4} \mathrm{H}_{9}+$ $\mathrm{H}_{2} \mathrm{O} \rightarrow-\mathrm{OH}+\mathrm{C}_{4} \mathrm{H}_{9} \mathrm{OH}$ による親水性化への逆戻りの可能 性は否定できない、しかし，ブトキシ化したシリカゲル を室温水中に浸漬し攪拌の後, 乾燥試料粉末の水に対す る浸漬熱変化は殆んど認められないが，水中で煮沸する

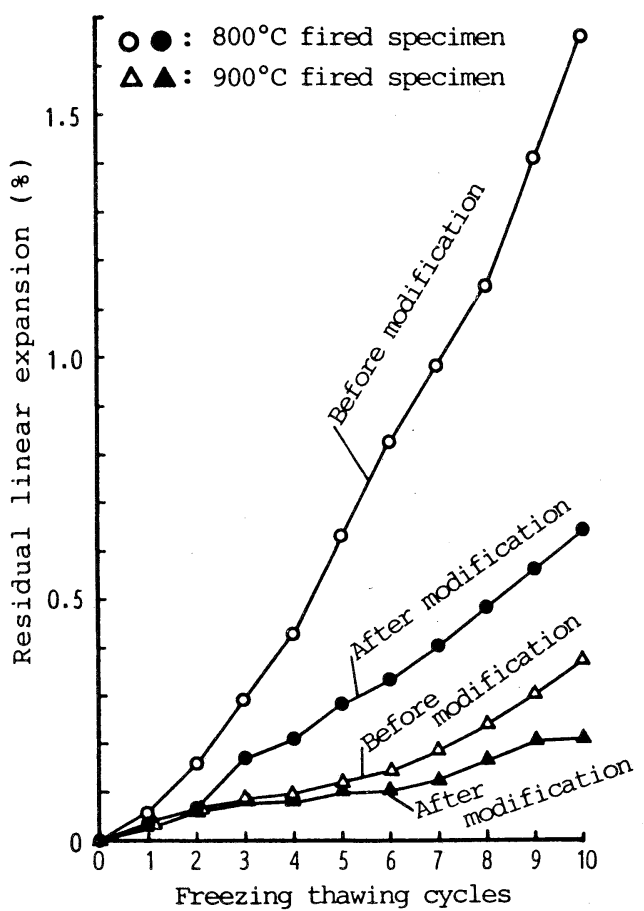

Fig. 3. Effect of internal surface modification by $n$ butanol on frost damage of two kind clay roofing tile specimens. Freezing and thawing cycles were repeated under unidirectional cooling condition at $7^{\circ} \mathrm{C} / \mathrm{min}$ between $-42^{\circ} \mathrm{C}$ and room temperature on the cooled bottom surface of the specimens. 
と浮遊していた改質粉末は，水中に一部沈降する報告5) を参考にすると，瓦試料に対しても室温での水との接触 によるブトキシ基の分解反応は少ないものと考えられ る.

\section{2 耐凍害性の改善効果の検討}

表面改質による瓦試料の耐凍害性の改善効果を, 図 3 にまとめて示す．表面改質の確認の項で示したように， $800^{\circ} \mathrm{C}$ 焼成瓦試料では, $900^{\circ} \mathrm{C}$ 焼成瓦に比較して顕著な 改質効果が認められる。しかし, 残留線膨張率值は $900^{\circ} \mathrm{C}$ 焼成瓦の改質処理試料が最も小さく, 耐凍害性の 実用的な改善効果が期待できる.図 3 に示されるように, $800^{\circ} \mathrm{C}$ 及び $900^{\circ} \mathrm{C}$ 焼成の各未処理瓦試料の凍害性の差 異は, 別報》のように, 気孔径分布及び機械的強度の差 異によるものであり，図1に示すように, メディアン気 孔半径が大きく, かつ吸水率が低く, 機械的強度が高い $900^{\circ} \mathrm{C}$ 焼成瓦の方が耐凍害性は高い.

耐凍害性に対する表面改質の効果が，〔゙の程度の長期 間にわたって持続するかについては，更に詳細な検討を 要すが, 既述のように, 改質表面が水と接する場合には, 低温ほビブトキシ基の分解反応が少ないものと考えられ る.

\section{4. 総 括}

粘土瓦の耐凍害性改善のための低廉で簡便な表面改質
技術を探る目的で，本実験では $n$-ブタノール中で瓦を 還流煮沸する方法に着目し，本改質法の可能性及び耐凍 害性の向上への効果について検討し, 以下の結論を得た.

（1） $800^{\circ} \mathrm{C}$ 及び $900^{\circ} \mathrm{C}$ で焼成した粘土瓦を 24 時間, $n$-ブタノール中で還流煮沸すると, 瓦試料の内表面に ブトキシ基が置換することが，改質処理及び未処理瓦の 両試料の吸水率及び赤外吸収スペクトル分析結果の比較 から判明した。

（2）上記 2 種の焼成瓦の飽水試料を一方向凍結融解 試験を行い，凍害破壊量の目安として，冷却方向（瓦の 厚さ方向）の残留線膨張率を比較した結果, 改質処理に より，耐涷害性は向上することが分かった。

辞 本実験を進めるに際し，粘土瓦試料の提供を頂い た兵庫県淡路瓦共同組合 石井貴興氏に感謝します。

\section{文献}

1）中村雅彦, 都賀谷紀宏, 奥田 進, 窑協, 85, 549-54 (1977).

2）中村雅彦，奥田 進，P.P. Hudec，空協，92, 105-11 (1984).

3） 中村雅彦, 浜 昭徳, 松本晋一, 奥田 進, P. P. Hudec, 窯協, 94, 1149-56 (1986).

4) M. Nakamura, Y. Nabika and S. Okuda, Am Ceram. Soc. Bull., 64, 1567- 70 (1985).

5）堤 和男, 高橋. 浩, 日化, 9, 1800-805 (1972).

6）中村雅彦，奥田 進，䈉協，84，325-32 (1976).

7） 中村雅彦, 奥田 進, 窯協, 84, 30-34 (1976).

8）土屋 勲, 表面, 7, 160-72 (1969). 